\title{
Can the Meat from Angus Crossbreds with Bos indicus Dams Compete with that from Bos taurus Dams in Organoleptic Properties and Fatty Acid Profile?
}

\author{
Niraporn CHAIWANG ${ }^{1}$, Thanaporn BUNMEE ${ }^{2}$, Kittipong SAMOOTKWAM ${ }^{3}$, \\ Bulgul TIPNATE ${ }^{4}$, Amphon WARITTHITHAM ${ }^{5}$, \\ Michael KREUZER ${ }^{6}$ and Sanchai JATURASITHA ${ }^{3, *}$ \\ ${ }^{1}$ Department of Agricultural Technology and Development, Faculty of Agricultural Technology, \\ Chiang Mai Rajabhat University, Chiang Mai 50300, Thailand \\ ${ }^{2}$ Division of Animal Sciences, School of Agriculture and Natural Resources, University of Phayao, \\ Phayao 56000, Thailand \\ ${ }^{3}$ Department of Animal and Aquatic Sciences, Faculty of Agriculture, Chiang Mai University, \\ Chiang Mai 50200, Thailand \\ ${ }^{4}$ Chiang Mai Fresh Milk Farm Company, Chiang Mai, Chiang Mai 50140, Thailand \\ ${ }^{5}$ Livestock Industry Development Center, Chiang Mai 50300, Thailand \\ ${ }^{6}$ ETH Zurich, Institute of Agricultural Sciences, Universitaetstrasse 2, Zurich, Switzerland
}

("Corresponding author's e-mail: ja.sanchai@gmail.com)

Received: 26 March 2018, Revised: 9 July 2018, Accepted: 10 August 2018

\begin{abstract}
It was experimentally determined whether crossbreeding with Bos indicus dams compared to Bos taurus dams may provide meat which is competitive in organoleptic properties and fatty acid (FA) profile and if tenderness, assumed to be lower, is really adversely affected. Eight Black Angus $\times$ White Lamphun $(\mathrm{A} \times \mathrm{W})$ bulls were compared with 8 Black Angus $\times$ Holstein Friesian $(\mathrm{A} \times \mathrm{H})$. M. longissimus thoracis, M. semimembranosus and M. infraspinatus were analyzed for organoleptic properties and objective explanatory properties related to tenderness, as well as FA profile.

Tenderness was judged lower in the M. infraspinatus of $\mathrm{A} \times \mathrm{W}$ than $\mathrm{A} \times \mathrm{H}$, but not in the other muscles. Shear force and collagen solubility tended $(\mathrm{P}<0.10)$ to be lower in all 3 muscles of $\mathrm{A} \times \mathrm{W}$ compared to those of $\mathrm{A} \times \mathrm{H}$. The fat content of the M. longissimus thoracis from $\mathrm{A} \times \mathrm{W}$ was lower than that from $\mathrm{A} \times \mathrm{H}$. The lipids in the $M$. longissimus thoracis from $\mathrm{A} \times \mathrm{W}$ were richer in polyunsaturated $\mathrm{FA}$ and total n-3 FA, and poorer in C18:0 and saturated FA than those of $\mathrm{A} \times \mathrm{H}$. Furthermore, the lipids of the $M$. semimembranosus from $\mathrm{A} \times \mathrm{W}$ had higher proportions of $\mathrm{C} 14: 1$ and $\mathrm{C} 16: 1$ than that of $\mathrm{A} \times \mathrm{H}$. The $\mathrm{FA}$ in the $M$. infraspinatus from $\mathrm{A} \times \mathrm{W}$ had higher proportions of $\mathrm{C} 18: 3 \mathrm{n}-3$, mono-unsaturated FA and total n-3 $\mathrm{FA}$ and the proportion of saturated FA was lower than in $\mathrm{A} \times \mathrm{H}$. The M. infraspinatus from $\mathrm{A} \times \mathrm{W}$ was lower in cholesterol content than that from $\mathrm{A} \times \mathrm{H}$. There were some differences in tenderness (inferior in White Lamphun crossbreds) and FA profile (superior in White Lamphun crossbreds), but differences were numerically small and, thus, may be of low practical relevance. Therefore, crossbreeding with indigenous Bos indicus cattle does not seem to be restricted by low meat quality.
\end{abstract}

Keywords: White Lamphun, Angus, Holstein, crossbred, meat tenderness, fatty acid 
http://wjst.wu.ac.th

\section{Introduction}

Traditionally, most beef in Thailand has been produced by native breeds. However, the decrease of the native cattle population observed in recent years has threatened to reduce the level of beef production. White Lamphun cattle, an indigenous B. indicus breed, is widespread in the northern region of Thailand. It is well adapted to the hot climate, is very fertile, and has low requirements with respect to management and nutrition. On smallholder farms, White Lamphun are used as draft animals and the cows are kept for calf production. In recent years, a high-quality beef market has steadily developed in Thailand. Thai native beef cattle are relatively light and have a poor growth performance [1]. Butchers prefer heavy carcasses and, therefore, the average carcass weight of slaughter animals has substantially increased in Thailand recently. Another constraint of $B$. indicus cattle and their crosses is that they are expected to produce meat with low tenderness [2]. Still, crossbreeding between B. taurus and B. indicus has been a common practice in the beef cattle industry for a long time as a way to improve productivity in both the dam and calf [3].

Based on this scenario, we were interested in the efficiency of crossbreeding to improve the performance and beef quality of native cattle breeds. In this respect, Thai native dams have to compete with dams of the Holstein Friesian breed, a B. taurus genotype, which is common in Thailand for intensive milk production and which is attractive in beef quality but is quite low in growth performance [4]. Holstein crossbreeding with a beef breed might, therefore, yield carcass and meat quality superior to that of indigenous cattle. Several studies have shown that breed is among the factors having influence on the sensory attributes and physicochemical properties of beef. This includes beef fat quality [5]. In this respect, the breed effect on the fatty acid (FA) profile is mostly mediated via the effect on overall fat content, as fat depots have high proportions of neutral lipids, whereas functional lipids are rich in phospholipids in the muscle [6]. The latter are richer in polyunsaturated FA (PUFA). Indeed, experimental evidence suggests that there is a genetic influence on the FA profiles of beef cattle, with important differences between B. taurus and B. indicus cattle [7]. Also, the within-breed variability observed in FA profile has initiated attempts of improvement by selection [8]. Consumers prefer beef which is not only tender, but also has a high quality with respect to nutrition and health [9], including a favorable fatty acid profile and a low cholesterol content, as consumers' awareness of the nutritional value of foods which may promote health and prevent diseases [10] is increasing. Jaturasitha et al. [11] recently compiled information about how to deal with these issues from a producer's point of view. One of these options, crossbreeding of indigenous cattle with beef breeds, was selected to be studied in closer detail in the present experiment.

The main hypothesis tested in the present study was that the meat from crossbreds with $B$. indicus dams is superior to that from B. taurus dams in the fatty acid composition of the intramuscular fat, even though the meat may be inferior in tenderness. For this purpose, meat was investigated that originated from an experiment where carcass and selected other meat quality traits, like $\mathrm{pH}$, color, water-holding capacity, chemical composition, and oxidative stability (M. longissimus thoracis (LT) only) have been described [12]. The experiment had been performed with crossbreds having White Lamphun and Holstein cattle as dam breeds. As a sire breed, Angus, one of the most intensively growing and early maturing beef breeds, was chosen. Some cattle farm data are available from Angus $\times$ White Lamphun $(\mathrm{A} \times \mathrm{W})$ crosses. However, for this crossbred type, meat quality still remains to be explored. By contrast, data on the performance of Angus $\times$ Holstein $(\mathrm{A} \times \mathrm{H})$ crossbred are registered and have long been reported[13]. No comparative information about the sensory quality and nutritive properties of the meat of these 2 crossbred types is available. 


\section{Materials and methods}

\section{Animal caretaking}

The experimental procedure was approved by the Thai Institute of Animal Care Development for Science (approval number U1-0380-2559).

\section{Animal, experimental design, and diet}

A completely randomized experimental design was applied. Eight bulls of each crossbred type were randomly selected to be slaughtered at 20 to 24 months of age in order to obtain meat samples for the determination of the differences between crossbred types in meat quality. During fattening, the bulls were fed $3 \mathrm{~kg}$ of commercial concentrate containing $16 \%$ crude protein and, additionally, roughage (fresh or silage) at ad libitum access. They had also free access to drinking water. Bulls were fattened at a commercial farm (Chiang Mai Fresh Milk Company, Thailand) and were slaughtered in a local abattoir, applying current industry practices. Live weights at slaughter and chilled carcass weights were $319 \pm 73$ and $334 \pm 57$, as well as $167 \pm 45$ and $169 \pm 30 \mathrm{~kg}$ (means \pm standard deviations) for $\mathrm{A} \times \mathrm{H}$ and $\mathrm{A} \times \mathrm{W}$, respectively, and there were only minor differences in muscularity (loin eye area) and carcass fatness (back fat thickness) (for details see [12]). Twenty-four hours after exsanguination, samples from 3 muscles were obtained and trimmed of adhering fat. Muscles included the M. Iongissimus thoracis (LT) (from between the $6^{\text {th }}$ and $12^{\text {th }} \mathrm{rib}$ ), the M. semimembranosus (SM), and the M. infraspinatus (IS). All samples were cut into $2.54 \mathrm{~cm}$ thickness meat slices, vacuum packed, and kept at $-20{ }^{\circ} \mathrm{C}$ for later analysis.

Sensory attributes were evaluated by an 8-member group of trained panelists, scoring the cooked beef steak according to the procedures outlined by AMSA [14]. The samples of each individual animal and muscle were covered with aluminum foil and heated to an internal temperature of $70{ }^{\circ} \mathrm{C}$ in a convection oven pre-heated to $200^{\circ} \mathrm{C}$. The internal temperatures were monitored by a copper thermocouple (consort T851, Cohaset, MA, USA). Pieces of a size of $1.5 \times 1.5 \times 2.54 \mathrm{~cm}^{3}$ were cut and served warm in triplicate to each panel member. Samples were served subsequently to each other in a randomized order with respect to crossbred type and animal. All 48 samples (3 muscles from 16 animals each) were tested by every panelist. The panelists rated samples for tenderness, firmness, flavor intensity, juiciness, and overall acceptability, using a 9-point scale with $1=$ highly unfavorable and $9=$ highly favorable.

Meat slices were subjected to the Warner-Bratzler method to determine shear values after having been put into plastic bags and heated at $80{ }^{\circ} \mathrm{C}$ in a water bath (Korimat Model 120/1.6, Christian Wanger, Esslingen, Germany) until a meat core temperature of $70{ }^{\circ} \mathrm{C}$ was reached. Core temperature was measured with the same device that had been applied during cooking of meat for sensory analysis. The meat was then allowed to cool to room temperature. Six cores (diameter of $1.27 \mathrm{~cm}$ ) were manually obtained from each meat sample in parallel to the longitudinal orientation of the muscle fibers using a hand-held coring device. Maximal shear force and shear energy were measured using a Warner-Bratzler shear blade mounted on a texture analyzer (Model-TA.XT plus Stable Micro System LTD., London, UK.). A crosshead speed of $200 \mathrm{~mm} / \mathrm{min}$ with a $5 \mathrm{kN}$ load cell was used, calibrated to read over a range of 0 to $100 \mathrm{~N}$ [cf 15].

Contents of total insoluble and soluble collagen were determined in $15 \mathrm{~g}$ of minced, homogenized meat (12,000 rpm for $20 \mathrm{~min}$ at $4{ }^{\circ} \mathrm{C}$ ) using a Nissel Am-8 homogenizer (Nihonseikikaisha Ltd, Japan). Samples were subsequently heated in a water bath at $77^{\circ} \mathrm{C}$ for $63 \mathrm{~min}$ in 0.25 strength Ringer's solution [16]. After homogenization, supernatant and residue were individually hydrolyzed in $6 \mathrm{M} \mathrm{HCl} \mathrm{for} 18 \mathrm{~h}$ at $121^{\circ} \mathrm{C}$. The residue was neutralized with $5 \mathrm{M} \mathrm{NaOH}$. The content of hydroxyproline was determined in duplicate for both hydrolysate and residue solutions by a spectrophotometric method [16]. Proportions of soluble and insoluble collagen were calculated by multiplying the hydroxyproline content by 7.25 and 7.52 for the residue and the supernatant, respectively. Collagen solubility was calculated as the proportion of soluble collagen of the sum of soluble and insoluble collagen.

Intramuscular fat content and cholesterol were determined in meat samples thawed at 2 to $4{ }^{\circ} \mathrm{C}$ for $24 \mathrm{~h}$ in a refrigerator. The samples were ground in a household blender (Moulinex, model DPA1) and then subjected to standard ether extract analysis as the measure for intramuscular fat [17]. Cholesterol 
http://wjst.wu.ac.th

was quantified after extraction of the fat [18] and its saponification. In the residual extract, cholesterol was measured colorimetrically [19].

The fatty acid composition of the intramuscular fat was determined in samples drawn from the interior of each muscle and ground using a blender (Moulinex; model DPA1). Lipid extraction was done by a mixture of chloroform and methanol $(2: 1 ; \mathrm{v} / \mathrm{v})[18]$. Approximately $15 \mathrm{~g}$ of the muscle sample was homogenized for $2 \mathrm{~min}$ with $90 \mathrm{ml}$ of the chloroform-methanol solution (Nissel AM-8 Homogenizer, Nihonseikikaisha, Ltd., Japan). Fatty acid methyl esters were prepared according to Morrison and Smith [20]. Gas chromatographic analysis was accomplished with model GC-14B of Shimadzu (Kyoto, Japan) equipped with a $0.25 \mathrm{~mm} \times 100 \mathrm{~m} \times 0.25 \mu \mathrm{m}$ wall-coated fused wax capillary column. The carrier gas was nitrogen. Oven temperature programming included an increase from 50 to $220^{\circ} \mathrm{C}$ at a rate of 10 ${ }^{\circ} \mathrm{C} / \mathrm{min}$, held for $35 \mathrm{~min}$, up from 200 to $230{ }^{\circ} \mathrm{C}$ at a rate of $5^{\circ} \mathrm{C} / \mathrm{min}$, and then held at $230{ }^{\circ} \mathrm{C}$ for $20 \mathrm{~min}$. The injector volume was $1 \mu \mathrm{l}$ and the temperature of the flame ionization detector was $250{ }^{\circ} \mathrm{C}$. Chromatograms were processed using the Millennium 2010 Chromatography Manager (Millipore Corp., Milford, Massachusetts, USA). Identification was accomplished by comparing the retention time of peaks from the samples with those of FAME standard mixtures (Supelco ${ }^{\circledR} 37$ Component FAME Mix). The quantification of FAME was based on an internal standard (margaric acid, C17:0) and on the conversion of the relative peak areas into weight percentages, using the true response factor of each fatty acid (ES ISO 5508, 1990). Fatty acids were expressed as proportions of the sum of all fatty acids identified.

\section{Statistical analysis}

Data were subjected to analysis of variance. The significance of the differences between the 2 crossbred types were statistically analyzed by an independent 2-tailed Student's t-test. Breed differences were considered significant at $\mathrm{P}<0.05$, and $0.05 \leq \mathrm{P}<0.10$ was considered as a trend. All calculations were performed with SAS version 6.12 (SAS Institute Inc. Cary, NC, USA).

\section{Results and discussion}

The sensory analysis showed that the attribute tenderness was judged less favorable $(\mathrm{P}<0.05)$ in the IS of the $\mathrm{A} \times \mathrm{W}$ compared to $\mathrm{A} \times \mathrm{H}$, but scores did not significantly differ in LT and SM (Table 1). The scores for the attributes of firmness, beef flavor intensity, juiciness, and overall acceptability were not statistically different between crossbred types in any of the muscles investigated. Differences between crossbred types in terms of shear force and shear energy approached significance $(\mathrm{P}<0.10)$ in the IS, with higher force and energy needed for the IS of $\mathrm{A} \times \mathrm{W}$ compared to $\mathrm{A} \times \mathrm{H}$. The content of soluble collagen tended $(\mathrm{P}<0.10)$ to be lower in $\mathrm{A} \times \mathrm{W}$ compared to $\mathrm{A} \times \mathrm{H}$ in $\mathrm{SM}$ and IS, and in all 3 muscles of $\mathrm{A} \times \mathrm{W}$ compared to $\mathrm{A} \times \mathrm{H}$ there was a trend $(\mathrm{P}<0.10)$ towards a lower collagen solubility. The intramuscular fat content of the LT from $\mathrm{A} \times \mathrm{W}$ was lower $(\mathrm{P}<0.05)$ than that of the $\mathrm{A} \times \mathrm{H}$, whereas the differences in the other muscles were not significant. The IS from the $\mathrm{A} \times \mathrm{H}$ was lower $(\mathrm{P}<0.05)$ in cholesterol than that from the $\mathrm{A} \times \mathrm{W}$, and the same trend $(\mathrm{P}<0.10)$ was apparent in the 2 other muscles.

The contents of only a few fatty acids in the intramuscular fat of the LT differed $(\mathrm{P}<0.05)$ between breed types (Table 2). The LT from the $\mathrm{A} \times \mathrm{W}$ had higher $(\mathrm{P}<0.05)$ proportions of $\mathrm{C} 17: 1$, PUFA, and total n-3 in total fatty acids, as well as a higher PUFA:saturated FA (SFA) ratio than the LT from $\mathrm{A} \times \mathrm{H}$ cattle. In turn, the LT from $\mathrm{A} \times \mathrm{W}$ presented higher $(\mathrm{P}<0.05)$ proportions of C18:0 and SFA in total fatty acids than that of $\mathrm{A} \times \mathrm{H}$ cattle. The lipids of the $\mathrm{SM}$ from the $\mathrm{A} \times \mathrm{W}$ cattle had higher $(\mathrm{P}<0.05)$ proportions of $\mathrm{C} 14: 1, \mathrm{C} 16: 1$, and $\mathrm{C} 17: 1$ fatty acids in total fatty acids than the SM of the $\mathrm{A} \times \mathrm{H}$ cattle. In the IS from the $\mathrm{A} \times \mathrm{W}$, proportions of $\mathrm{C} 18: 3 \mathrm{n}-3$, mono-unsaturated FA (MUFA), and total $\mathrm{n}-3$ fatty acids in total fatty acids were higher $(\mathrm{P}<0.05)$ than that of the $\mathrm{A} \times \mathrm{H}$ cattle. In compensation, the IS of the $\mathrm{A} \times \mathrm{W}$ had lower $(\mathrm{P}<0.05)$ proportions of SFA in total fatty acids than that of the $\mathrm{A} \times \mathrm{H}$ cattle. The proportion of the conjugated linoleic acid isomer $\mathrm{C} 18: 2$ cis- 9 , trans-11 in total fatty acids showed a trend $(\mathrm{P}<0.10)$ to be higher in $\mathrm{LT}$ and $\mathrm{SM}$ of $\mathrm{A} \times \mathrm{W}$ compared to $\mathrm{A} \times \mathrm{H}$ cattle. 
http://wjst.wu.ac.th

Table 1 Sensory perception and explanatory variables for tenderness of 3 different muscles obtained from 2 crossbred types (mean $\pm \mathrm{SD})$.

\begin{tabular}{|c|c|c|c|c|c|c|c|c|c|}
\hline & \multicolumn{3}{|c|}{ Longissimus thoracis } & \multicolumn{3}{|c|}{ Semimembranosus } & \multicolumn{2}{|c|}{ Infraspinatus } & \multirow[b]{2}{*}{$P$-value } \\
\hline Trait $\quad$ Crossbred & $\mathbf{A} \times \mathbf{H}$ & $\mathbf{A} \times \mathbf{W}$ & $P$-value & $\mathbf{A} \times \mathbf{H}$ & $\mathbf{A} \times \mathbf{W}$ & $P$-value & $\mathbf{A} \times \mathbf{H}$ & $\mathbf{A} \times \mathbf{W}$ & \\
\hline \multicolumn{10}{|l|}{ Sensory evaluation ${ }^{1)}$} \\
\hline Tenderness & $6.48 \pm 6.03$ & $6.35 \pm 0.66$ & 0.792 & $5.30 \pm 1.097$ & $5.00 \pm 1.182$ & 0.612 & $6.88 \pm 0.83^{\mathrm{b}}$ & $6.09 \pm 1.05^{\mathrm{a}}$ & 0.032 \\
\hline Firmness & $5.65 \pm 0.58$ & $6.06 \pm 0.68$ & 0.222 & $6.44 \pm 0.188$ & $6.65 \pm 0.573$ & 0.332 & $5.83 \pm 0.65$ & $6.17 \pm 0.37$ & 0.221 \\
\hline Flavor intensity & $5.75 \pm 0.55$ & $5.92 \pm 0.34$ & 0.478 & $5.66 \pm 0.345$ & $5.68 \pm 0.291$ & 0.842 & $5.89 \pm 0.499$ & $6.17 \pm 0.313$ & 0.202 \\
\hline Juiciness & $6.03 \pm 1.19$ & $6.06 \pm 0.94$ & 0.955 & $5.33 \pm 0.807$ & $4.85 \pm 1.321$ & 0.409 & $6.48 \pm 0.74$ & $6.34 \pm 0.90$ & 0.738 \\
\hline Overall acceptability & $5.92 \pm 0.85$ & $6.09 \pm 0.208$ & 0.594 & $5.72 \pm 0.503$ & $5.33 \pm 0.722$ & 0.232 & $6.60 \pm 0.58$ & $6.25 \pm 0.75$ & 0.306 \\
\hline \multicolumn{10}{|l|}{ Shear values } \\
\hline Force $(\mathrm{N})$ & $63.2 \pm 1.4$ & $66.4 \pm 2.6$ & 0.067 & $65.2 \pm 2.6$ & $67.3 \pm 2.0$ & 0.083 & $41.7 \pm 2.6$ & $44.7 \pm 2.2$ & 0.061 \\
\hline Energy (MJ) & $6.45 \pm 0.13$ & $6.78 \pm 0.43$ & 0.078 & $6.65 \pm 0.32$ & $6.87 \pm 0.49$ & 0.076 & $4.25 \pm 0.96$ & $4.56 \pm 0.56$ & 0.059 \\
\hline \multicolumn{10}{|l|}{ Collagen content $(\mathrm{g} / 100 \mathrm{~g})$} \\
\hline Total collagen & $3.62 \pm 0.14$ & $3.87 \pm 0.12$ & 0.125 & $5.79 \pm 1.71$ & $5.58 \pm 1.42$ & 0.659 & $7.12 \pm 1.44$ & $7.56 \pm 1.14$ & 0.785 \\
\hline Insoluble collagen & $2.84 \pm 0.25$ & $3.12 \pm 0.41$ & 0.071 & $4.31 \pm 1.47$ & $4.44 \pm 1.62$ & 0.895 & $5.23 \pm 1.23$ & $5.75 \pm 1.25$ & 0.061 \\
\hline Soluble collagen & $0.78 \pm 0.31$ & $0.75 \pm 0.28$ & 0.248 & $1.48 \pm 0.14$ & $1.14 \pm 0.23$ & 0.066 & $1.59 \pm 0.70$ & $1.81 \pm 0.48$ & 0.096 \\
\hline Collagen solubility (\%) & $21.5 \pm 3.5$ & $19.4 \pm 2.2$ & 0.056 & $25.6 \pm 1.5$ & $20.4 \pm 2.1$ & 0.071 & $26.5 \pm 2.4$ & $23.9 \pm 2.4$ & 0.089 \\
\hline Intramuscular fat $(\mathrm{g} / 100 \mathrm{~g})$ & $3.09 \pm 0.99^{\mathrm{b}}$ & $1.56 \pm 0.55^{\mathrm{a}}$ & 0.048 & $1.97 \pm 0.73$ & $1.54 \pm 0.49$ & 0.185 & $3.73 \pm 2.03$ & $3.11 \pm 1.65$ & 0.518 \\
\hline Cholesterol $(\mathrm{mg} / 100 \mathrm{~g})$ & $43.3 \pm 1.85$ & $40.5 \pm 1.31$ & 0.052 & $43.2 \pm 1.74$ & $40.9 \pm 1.13$ & 0.058 & $50.8 \pm 1.35^{\mathrm{b}}$ & $46.8 \pm 2.04^{\mathrm{a}}$ & 0.043 \\
\hline
\end{tabular}

Note: $\mathrm{A} \times \mathrm{H}=$ Black Angus $\times$ Holstein Friesian; $\mathrm{A} \times \mathrm{W}=$ Black Angus $\times$ White Lamphun.

Data are arithmetic means \pm standard deviations from 8 replicates.

a,b Means within the same row with different superscripts differ significantly $(\mathrm{P}<0.05)$.

1) 1 = highly unfavorable, $5=$ average, $9=$ highly favorable.

\section{Effect of crossbred type on tenderness of the meat}

One main focus of this investigation was on whether or not tenderness is influenced by crossbreeding either White Lamphun or Holstein Friesian with Angus. This was assessed by sensory testing, physical resistance to shearing, and compositional variables known to influence tenderness, such as collagen content and solubility. In the case of a generally substantial proportion, a higher intramuscular fat content may also lower the muscle's resistance against being sheared, because of the dilution of the myofibers by the softer fat $[21,22]$. The sensory grading revealed a lower tenderness impression in one muscle (IS) of the $B$. indicus compared to the $B$. taurus crossbred type, whereas the difference was not significant in the other muscles. Still, trends in shear force substantiated a tendency for a lower tenderness of the $\mathrm{A} \times \mathrm{W}$ compared to the $\mathrm{A} \times \mathrm{H}$ meat. The shear force measured in the meat of all animals was, on average, beyond the threshold of $40 \mathrm{~N}$, indicating tender beef [23], and the level of improvement achieved with the more favorable crossbred type was not sufficiently large to counteract this limitation. Explanations for the trend towards a lower tenderness in $\mathrm{A} \times \mathrm{W}$ compared to the $\mathrm{A} \times \mathrm{H}$ meat particularly include the tendency for a lower collagen solubility in the first. If this is really the case, extended cooking times for the meat to equalize the difference between crossbred types would prove useless. In the present study, total collagen content of the meat (LT) was lower than that found in other studies [24]. Earlier maturing breeds seem to deposit more collagen, with a greater proportion of insoluble material [25], whereas fast growing late maturing breeds have been reported to deposit more soluble collagen than earlier maturing breeds [24]. In the present study, both crossbred types were of similar age and slaughter weights [12], which is why the differences in the content of soluble collagen and in collagen solubility had to be dependent on dam breed. In this sense, Holstein showed a trend to be superior to White Lamphun concerning content of insoluble collagen (LT and IS) and collagen solubility (SM and IS). Still, the effect on the sensory impression of tenderness was limited. Some authors found occasionally no relationship between collagen content [26] or solubility [27] on one hand, and tenderness on the other hand, but in the present study, trends in collagen variables and tenderness/shear force at least numerically coincided. This was also the case for intramuscular fat content of the LT, which was lower in $\mathrm{A} \times \mathrm{W}$ than 
http://wjst.wu.ac.th

$\mathrm{A} \times \mathrm{H}$. However, this difference was not significant in the other muscles and, therefore, likely was not a major reason causing the trends in tenderness.

Table 2 Fatty acid profiles (given as percentages of the total fatty acids identified or as ratios) of the 3 different muscles obtained from the 2 crossbred types (mean $\pm \mathrm{SD})$.

\begin{tabular}{|c|c|c|c|c|c|c|c|c|c|}
\hline \multirow{2}{*}{$\begin{array}{r}\text { Muscle } \\
\text { Crossbred }\end{array}$} & \multicolumn{3}{|c|}{ Longissimus thoracis } & \multicolumn{3}{|c|}{ Semimembranosus } & \multicolumn{3}{|c|}{ Infraspinatus } \\
\hline & $\mathbf{A} \times \mathbf{H}$ & $\mathbf{A} \times \mathbf{W}$ & $P$-value & $\mathbf{A} \times \mathbf{H}$ & $\mathbf{A} \times \mathbf{W}$ & $P$-value & $\mathbf{A} \times \mathbf{H}$ & $\mathbf{A} \times \mathbf{W}$ & $P$-value \\
\hline C12:0 & $0.28 \pm 0.09$ & $0.20 \pm 0.07$ & 0.059 & $0.18 \pm 0.05$ & $0.21 \pm 0.07$ & 0.405 & $0.27 \pm 0.06$ & $0.33 \pm 0.20$ & 0.494 \\
\hline $\mathrm{C} 14: 0$ & $3.97 \pm 0.96$ & $3.13 \pm 1.15$ & 0.131 & $3.06 \pm 0.38$ & $2.76 \pm 0.70$ & 0.297 & $3.71 \pm 0.47$ & $3.84 \pm 0.74$ & 0.708 \\
\hline C14:1 & $0.56 \pm 0.24$ & $0.71 \pm 0.30$ & 0.278 & $0.39 \pm 0.14^{\mathrm{a}}$ & $0.67 \pm 0.24^{\mathrm{b}}$ & 0.014 & $0.79 \pm 0.48$ & $1.02 \pm 0.36$ & 0.409 \\
\hline C15:0 & $0.62 \pm 0.11$ & $0.57 \pm 0.21$ & 0.585 & $0.53 \pm 0.14$ & $0.63 \pm 0.12$ & 0.172 & $0.65 \pm 0.13$ & $0.77 \pm 0.18$ & 0.248 \\
\hline $\mathrm{C} 16: 0$ & $27.8 \pm 2.2$ & $26.7 \pm 1.1$ & 0.222 & $29.0 \pm 3.2$ & $27.3 \pm 1.6$ & 0.173 & $26.6 \pm 1.2$ & $24.3 \pm 3.4$ & 0.134 \\
\hline C16:1 & $2.93 \pm 0.64$ & $3.12 \pm 0.46$ & 0.526 & $2.53 \pm 0.85^{\mathrm{a}}$ & $3.54 \pm 0.46^{\mathrm{b}}$ & 0.014 & $3.36 \pm 0.83$ & $4.07 \pm 0.74$ & 0.226 \\
\hline $\mathrm{C} 17: 0$ & $1.34 \pm 0.40$ & $1.50 \pm 0.20$ & 0.330 & $1.09 \pm 0.19$ & $1.22 \pm 0.14$ & 0.122 & $1.52 \pm 0.39$ & $1.50 \pm 0.14$ & 0.877 \\
\hline C17:1 & $0.46 \pm 0.12^{\mathrm{a}}$ & $0.71 \pm 0.25^{\mathrm{b}}$ & 0.030 & $0.53 \pm 0.10^{\mathrm{a}}$ & $0.72 \pm 0.14^{\mathrm{b}}$ & 0.006 & $0.49 \pm 0.15$ & $0.59 \pm 0.16$ & 0.248 \\
\hline C18:0 & $20.4 \pm 2.0^{\mathrm{b}}$ & $18.5 \pm 1.1^{\mathrm{a}}$ & 0.035 & $20.8 \pm 3.6$ & $18.6 \pm 2.7$ & 0.181 & $20.6 \pm 2.1$ & $19.0 \pm 0.8$ & 0.065 \\
\hline C18:1 n-9 & $34.3 \pm 2.5$ & $36.0 \pm 2.0$ & 0.157 & $32.8 \pm 6.4$ & $34.7 \pm 2.1$ & 0.439 & $36.8 \pm 2.0$ & $38.0 \pm 1.9$ & 0.408 \\
\hline C18:2 n-6 & $2.62 \pm 0.35$ & $2.99 \pm 0.45$ & 0.274 & $3.64 \pm 0.58$ & $4.16 \pm 0.62$ & 0.426 & $2.54 \pm 0.85$ & $3.19 \pm 0.94$ & 0.334 \\
\hline C18:2 cis- 9 , trans- 11 & $0.50 \pm 0.81$ & $0.60 \pm 0.51$ & 0.080 & $0.49 \pm 0.98$ & $0.53 \pm 0.49$ & 0.071 & $0.48 \pm 0.34$ & $0.56 \pm 1.58$ & 0.186 \\
\hline C18:3 n-3 & $1.52 \pm 0.21$ & $2.05 \pm 0.68$ & 0.066 & $1.88 \pm 0.64$ & $1.98 \pm 0.71$ & 0.775 & $1.39 \pm 0.14^{\mathrm{a}}$ & $1.94 \pm 0.48^{\mathrm{b}}$ & 0.009 \\
\hline$C 20: 3 n-6$ & $0.40 \pm 0.19$ & $0.43 \pm 0.10$ & 0.705 & $0.64 \pm 0.29$ & $0.76 \pm 0.24$ & 0.375 & $0.63 \pm 0.23$ & $0.64 \pm 0.47$ & 0.935 \\
\hline C20:5 n-3 & $2.21 \pm 0.65$ & $2.73 \pm 0.58$ & 0.107 & $2.46 \pm 0.86$ & $2.27 \pm 0.48$ & 0.603 & $0.25 \pm 0.07$ & $0.26 \pm 0.07$ & 0.789 \\
\hline Total SFA & $54.5 \pm 2.5^{\mathrm{b}}$ & $50.6 \pm 1.0^{\mathrm{a}}$ & 0.005 & $54.7 \pm 2.5$ & $51.0 \pm 6.1$ & 0.140 & $53.3 \pm 1.8^{\mathrm{b}}$ & $49.7 \pm 3.4^{\mathrm{a}}$ & 0.027 \\
\hline Total MUFA & $38.3 \pm 3.0$ & $40.6 \pm 1.6$ & 0.150 & $36.2 \pm 3.0$ & $39.2 \pm 7.3$ & 0.303 & $41.4 \pm 1.7^{\mathrm{a}}$ & $43.7 \pm 2.0^{\mathrm{b}}$ & 0.04 \\
\hline Total PUFA & $7.25 \pm 1.60^{\mathrm{a}}$ & $8.80 \pm 0.82^{\mathrm{b}}$ & 0.029 & $9.11 \pm 1.59$ & $9.78 \pm 1.86$ & 0.413 & $5.29 \pm 0.55$ & $6.59 \pm 2.27$ & 0.145 \\
\hline Total n-6 & $3.02 \pm 0.93$ & $3.42 \pm 0.56$ & 0.294 & $4.28 \pm 0.93$ & $4.92 \pm 1.17$ & 0.328 & $3.17 \pm 0.46$ & $3.83 \pm 2.03$ & 0.398 \\
\hline Total n-3 & $3.73 \pm 0.81^{\mathrm{a}}$ & $4.74 \pm 0.69^{\mathrm{b}}$ & 0.014 & $4.34 \pm 0.08$ & $4.25 \pm 1.03$ & 0.863 & $1.64 \pm 0.18^{\mathrm{a}}$ & $2.20 \pm 0.47^{\mathrm{b}}$ & 0.013 \\
\hline PUFA:SFA ratio & $0.13 \pm 0.03^{\mathrm{a}}$ & $0.17 \pm 0.01^{b}$ & 0.007 & $0.17 \pm 0.03$ & $0.19 \pm 0.03$ & 0.130 & $0.10 \pm 0.01$ & $0.13 \pm 0.06$ & 0.114 \\
\hline$n-6: n-3$ ratio & $0.81 \pm 0.19$ & $0.73 \pm 0.18$ & 0.443 & $0.99 \pm 0.19$ & $1.16 \pm 0.33$ & 0.338 & $1.93 \pm 0.28$ & 1.740 .74 & 0.501 \\
\hline
\end{tabular}

Effect of crossbred type on other sensory attributes of the meat

The present results suggest that there is no major effect of using either B. taurus or B. indicus dam breeds on firmness, flavor, or juiciness as the further sensory attributes tested. Obviously, the trends of the differences observed in texture (shear values, tenderness impression) were not large enough to influence firmness impression or perceived juiciness (a trait often associated with tenderness) and, thus, overall acceptability. 
http://wjst.wu.ac.th

\section{Effect of crossbred type on fatty acid profile and cholesterol content of the meat}

The amount and the nature of the lipids stored in the muscle mainly depends on nutrition, digestion, intestinal absorption, hepatic metabolism, and lipid transport to the muscle [28]. In the present study, influences of feeding, gender, and age had been widely excluded, the first by offering the animals the same amounts of concentrate per unit of body weight and the same forage. However, certain differences by the ingestion of different amounts of forage cannot be totally excluded. There are several ways how breed type differences in the fatty acid profile of the meat lipids could be explained. One is that there is an important breed type effect on the overall fat content of the muscles and, associated with this, the relative proportions and fatty acid composition of the neutral lipids and phospholipids [6], where phospholipids have a high PUFA proportion of in total lipids. Differences in fatty acid composition may also reflect possible genetic differences in fatty acid metabolism [29]. Accordingly, higher levels of the $\Delta 9$ desaturase (16) index were found in Simmental cattle compared to Red Angus cattle [30]. Other researchers [31] detected a higher $\Delta 9$-desaturase activity in Simmental compared to Charolais muscles, as derived from higher values of both $\Delta 9$-desaturase (16) and (18) indices. Finally, Purchas and Zou [32] described differences in the proportions of several MUFA in total fatty acids between breed types, including Angus, Belgian Blue crossbreds, Holstein Friesian, Charolais crossbreds, and Wagyu crossbreds. These authors attributed such differences to a higher activity of the $\Delta 9$ desaturase present in Wagyu than in Angus or other breed types. In a review, Smith et al. [33] suggested that breed types differ in their ability to accumulate MUFA in their adipose tissues. A second complex of explanations could be given by muscle fiber types. Red fibers have a higher proportion of phospholipids than white fibers and, therefore, a higher proportion of PUFA [34,35]. Accordingly, compared to the LT, the lipids in the redder leg muscle M. gluteobiceps was found to have a higher PUFA:SFA ratio, due to higher proportions of most PUFA in total fatty acids [36]. When put into this context, the present results overall showed a certain consistency for SFA being lower and PUFA being higher in proportion in the lipids of the meat of $\mathrm{A} \times \mathrm{W}$ compared to $\mathrm{A} \times \mathrm{H}$, but this was not found in all 3 muscles. Otherwise, there was no real consistency in the crossbred type differences in individual fatty acids across muscles. These results indicate that some of the present differences may have been random, despite reaching the level of significance. It may, therefore, also be questioned whether or not at least some of the studies quoted above were really describing genuine breed type effects, or whether some of these results were confounded with diet type and intake effects. It was also difficult to find consistency in breed type differences on the FA profiles of the muscles in the above quoted literature.

Cholesterol content is often considered to be associated with (intramuscular) fat content, a relationship apparent also in the present study, where the trend to lower intramuscular fat content in $\mathrm{A} \times \mathrm{W}$ compared to $\mathrm{A} \times \mathrm{W}$ was associated with a trend to a lower cholesterol content. This appears to restrict statements suggesting that breed does not affect the cholesterol concentration of bovine skeletal muscle [37] in situations where breeds are genetically not too far apart. However, it has also to be stated that the differences between the crossbred types found in the present study were rather small. Also, a Brazilian study showed a lower cholesterol content of the meat from Bos indicus bulls from a grass-based production system compared to that from B. taurus bulls [38]. However, the results of the latter study might have also be influenced by the finishing system applied [7]. Accordingly, cholesterol levels in $B$. taurus were higher than those $B$. indicus under a pasture-finishing regime (by about $9 \mathrm{mg} / 100 \mathrm{~g}$ meat), but were much higher for $B$. indicus compared to $B$. taurus in a grain feeding finishing system (by about $27 \mathrm{mg} / 100 \mathrm{~g}$ meat) [7]. When relating the present results to human nutritional aspects, the consumption of as much as $730 \mathrm{~g}$ of $\mathrm{A} \times \mathrm{W}$ beef (LT, SM) would represent a cholesterol intake which approaches the recommended maximum daily cholesterol intake of $300 \mathrm{mg}$ per day [39]. In this context, it is also important to state that, in humans, more than half of the amount of cholesterol in the body is synthesized in the liver and, therefore, foods provide less than half to the body's cholesterol pool [30]. 
http://wjst.wu.ac.th

\section{Conclusions}

The present study revealed some significant differences between the 2 breed types investigated in meat quality, as well as some trends for such differences. Overall, tenderness seemed to be inferior, and FA profiles superior, in the White Lamphun crossbreds compared to the Holstein crossbreds. However, the differences were numerically small and, thus, maybe of low practical relevance. This is particularly true for tenderness, because overall sensory acceptability did not differ in any of the muscles. Therefore, it can be concluded that the choice of the dam breed does not seem to be restricted by low meat quality. Further studies have to make comprehensive comparisons, including growth performance, feed efficiency, and carcass and meat quality to give sound advice to beef producers based on $B$. indicus crossbreds.

\section{Acknowledgements}

The authors would like to express their gratitude to the Functional Food Research Center for Wellbeing, which funded the research.

\section{References}

[1] S Jaturasitha, R Norkeaw, T Vearasilp, M Wicke and M Kreuzer. Carcass and meat quality of Thai native cattle fattened on Guinea grass (Panicum maxima) or Guinea grass-legume (Stylosanthes guianensis) pastures. Meat Sci. 2009; 81, 155-62.

[2] MA Elzo, DD Johnson, JG Wasdin and JD Driver. Carcass and meat palatability breed differences and heterosis effects in an Angus Brahman multi breed population. Meat Sci. 2012; 90, 87-92.

[3] LT Gama, MC Bressan, EC Rodrigues, LV Rossato, OC Moreira, SP Alves and RJB Bessa. Heterosis for meat quality and fatty acid profiles in crosses among Bos indicus and Bos taurus finished on pasture or grain. Meat Sci. 2013; 93, 98-104.

[4] E Dransfield, JF Martin, D Bauchart, S Abouelkaram, J Lepetit and J Culiolo. Meat quality and composition of three muscles from French cull cows and young bulls. J. Anim. Sci. 2003; 76, 38799.

[5] C Cuvelier, A Clinquart, JF Hocquette, JF Cabaraux, I Dufrasne, L Istasse and JL Hornick. Comparison of composition and quality traits of meat from young finishing bulls from Belgian Blue, Limousin and Aberdeen Angus breeds. Meat Sci. 2006; 74, 522-31.

[6] JD Wood, M Enser, AV Fisher, GR Nute, RI Sheard, RI Richardson, SI Hughes and FM Whittington. Fat deposition, fatty acid composition and meat quality: A review. Meat Sci. 2008; 78, 343-58.

[7] MC Bressan, LV Rossato, EC Rodrigues, SP Alves, RJB Bessa, EM Ramos and LT Gama. Genotype $\times$ environment interactions for fatty acid profiles in Bos indicus and Bos taurus finished on pasture or grain. J. Anim. Sci. 2011; 89, 221-32.

[8] T Nogi, T Honda, F Mukai, T Okagaki and K Oyama. Heritabilities and genetic correlations of fatty acid compositions in Longissimus muscle lipid with carcass traits in Japanese Black cattle. J. Anim. Sci. 2011; 89, 615-21.

[9] TC Schroeder, TL Marsh and J Mintert. Beef Demand Determinants: Report Prepared for the National Cattlemen's Beef Association; 2000. Available at: http://www.agecon.ksu.edu/livestock /Extension\%20Bulletins/BeefDemandDeterminants.pdf, accessed January 2018.

[10] USDA. Dietary guidelines for Americans. Department of Agriculture and U.S. Department of Health and Human Services. $7^{\text {th }}$ eds. Washington, DC, USA: U.S. Government Printing Office; 2010.

[11] S Jaturasitha, N Chaiwang, A Kayan and M Kreuzer. Nutritional strategies to improve the lipid composition of meat, with emphasis on Thailand and Asia. Meat Sci. 2016; 120, 157-66.

[12] K Samootkwam, S Jaturasitha, B Tipnate, A Waritthitham, M Wicke and M Kreuzer. Effect of improving Lamphun cattle with Black Angus on carcass and meat quality. Agri. Agri. Sci. Proc. $2015 ; \mathbf{5}, 145-50$. 
http://wjst.wu.ac.th

[13] R Totusek, WE Sharp and I Rush. The performance of three and four year old Angus $\times$ Holstein crossbred cows under range conditions. Oklahoma Agricultural Station Miscellaneous Publications; 1972. Available from: beefextension.com/research_reports/research_56_94/rr72/rr72_6.pdf, accessed January 2018.

[14] AMSA. Research Guidelines for Cookery, Sensory Evaluation and Instrumental Tenderness Measurements of Fresh Meat. American Meat Science Association, Savoy, IL, 1995.

[15] T Bunmee, S Jaturasitha, M Kreuzer and M Wicke. Can calcium chloride injection facilitate the ageing-derived improvement in the quality of meat from culled dairy cows? Meat Sci. 2014; 96, $1440-45$.

[16] F Hill. The solubility of intramuscular collagen in meat animals of various ages. J. Food Sci. 1966; 31, 161-6.

[17] AOAC. Official Method of Analysis. Association of Official Analytical Chemists, Arlington, V.A.; 1995.

[18] T Folch, M Lees and GH Sloane-Stanley. Simple method for isolation and purification of total lipids from animal tissues. J. Biol. Chem. 1957; 226, 497-509.

[19] DH Jung, HG Biggs and WR Moorehead. Colorimetry of serum cholesterol with use of ferric acetate, uranyl acetate and ferrous sulfate/sulfuric acid reagents. Clin. Chem. 1975; 21, 1526-30.

[20] WR Morrison and LM Smith. Preparation of fatty acid methyl esters and dimethylacetals from lipids with boron fluoride-methanol. J. Lipid Res. 1964; 5, 600-8.

[21] SJ Boleman, RK Miller, MJ Buyck, HR Cross and JW Savell. Influence of realimentation of mature cows on maturity, color, collagen solubility and sensory characteristics. J. Anim. Sci. 1996; 74, 2187-94.

[22] M Vestergaard, M Therkildsen, P Henckel, LR Jensen, HR Anderson and K Sejrsen. Influence of feeding intensity, grazing and finishing feeding on meat and eating quality of young bulls and the relationship between muscle fibre characteristics, fibre fragmentation and meat tenderness. Meat Sci. 2000; 54, 187-95.

[23] W Branscheid, KO Honikel, G von Lengerken and K Troeger. Qualität von Fleisch und Fleischwaren. Deutscher Fachverlag, Frankfurt/Main, Germany, 1998, p. 921.

[24] F Monsón, C Sanudo and I Sierra. Influence of cattle breed and ageing time on textural meat quality. Meat Sci. 2004; 68, 595-602.

[25] MM Campo, P Santolaria, C Sanudo, J Lepetit, JL Olleta, B Panea and P Alberti. Assessment of breed type and ageing time effects on beef meat quality using two different texture devices. Meat Sci. 2000; 55, 371-8.

[26] R Field, R McCormick, V Balasubramanian, D Sanson, J Wise, D Hixon, M Riley and W Russell. Tenderness variation among loin steaks from $\mathrm{A}$ and $\mathrm{C}$ maturity carcasses of heifers similar in chronological age. J. Anim. Sci. 1997; 75, 693-9.

[27] Q Liu, KK Scheller, SC Arp DM Schaefer and SN Williams. Titration of fresh meat stability and malondialdehyde development with Holstein steers fed vitamin E-supplemented diets. J. Anim. Sci. 1996; 74, 117-26.

[28] Y Geay, D Bauchart, JF Hocquette and J Culioli. Effect of nutritional factors on biochemical, structural and metabolic characteristics of muscles in ruminants, consequences on dietetic value and sensorial qualities of meat. Reprod. Nutr. Develop. 2001; 41, 1-20.

[29] S De Smet, K Raes and D Demeyer. Meat fatty acid composition as affected by fatness and genetic factors: A review. Anim. Res. 2004; 53, 81-98.

[30] FL Laborde, IB Mandell, JJ Tosh, JW Wilton and JG Buchanan-Smith. Breed effects on growth performance, carcass characteristics, fatty acid composition, and palatability attributes in finishing steers. J. Anim. Sci. 2001; 79, 355-65.

[31] D Bureš, L Bartoň, R Zahrádková, V Teslík and M Krejčová. Chemical composition, sensory characteristics, and fatty acid profile of muscle from Aberdeen Angus, Charolais, Simmental, and Hereford bulls. Czech J. Anim. Sci. 2006; 51, 279-84.

[32] RW Purchas RW and M Zou. Composition and quality differences between the Longissimus and Infraspinatus muscles for several groups of pasture-finished cattle. Meat Sci. 2008; 80, 470-9. 
http://wjst.wu.ac.th

[33] S Smith, C Gill, D Lunt and M Brooks. Regulation of fat and fatty acid composition in beef cattle. Asian-Australas J. Anim. Sci. 2009; 22, 1225-33.

[34] E Pellattiero, A Cecchinato, F Tagliapietra, S Schiavon and G Bittante. Determination by GC $\times \mathrm{GC}$ of fatty acid and conjugated linoleic acid (CLA) isomer profiles in six selected tissues of lambs fed on pasture or on indoor diets with and without rumen-protected CLA. J. Agric. Food Chem. 2015; 63, 963-74.

[35] JD Wood, RI Richardson, GR Nute, AV Fisher, MM Campo and E Kasapidou. Effects of fatty acids on meat quality: A review. Meat Sci. 2003; 66, 21-32.

[36] M Enser, KG Hallett, B Hewett, GAJ Fursey and JD Wood and G Harrington. Fatty acid content and composition of UK beef and lamb muscle in relation to production system and implications for human nutrition. Meat Sci. 1998; 49, 329-41.

[37] DC Rule, MD Macneil and RE Short. Influence of sire growth potential, time on feed, and growingfinishing strategy on cholesterol and fatty acids of ground carcass and Longissimus muscle of beef steers. J. Anim. Sci. 1997; 75, 1525-33.

[38] MR Ruiz, M Matsushita, JV Visentainer, JA Hernandez, EL Ribeiro, A De, M Shimokomaki, JJ Reeves and NE Souza. Proximate chemical composition and fatty acid profiles of Longissimus dorsi from pasture fed LHRH immunocastrated, castrated and intact Bos indicus bulls. South. Afri. J. Anim. Sci. 2005; 35, 13-8.

[39] American Heart Association. Heart Disease and Stroke Statistics-Update. Dallas, TX: American Heart Association, 2008. 